\title{
LEARNING, CREATIVE COL(LABOR)ATION, AND KNOWLEDGE CULTURES
}

\author{
MICHAEL A. PETERS \\ mpeters@waikato.ac.nz \\ University of Waikato; \\ University of Illinois at Urbana-Champaign \\ PETAR JANDRIĆ \\ pjandric@tvz.hr \\ Global Center for Advanced Studies, \\ University of Applied Sciences in Zagreb; \\ (corresponding author)
}

\begin{abstract}
In this conversation, Michael A. Peters analyses the advent of knowledge cultures and their relationships to human learning. The first part of the conversation analyses social transformation towards the network society and links digital technologies to the making of the society of control. It analyses the dynamics between openness, capitalism, and anti-capitalism, and uses various recent examples to link that dynamics to democracy. The second part of the conversation links cybernetic capitalism to learning and knowledge production, and elaborates the movement of open education. Based on work of Paulo Freire, it develops the notion of openness as an (educational) virtue. It links openness and creativity, introduces Michael Peters' political economy of academic publishing, analyzes the importance of editing for learning and knowledge production, and briefly introduces the concept of knowledge cultures. The third part of the conversation shows practical applications of these theoretical insights using the examples of two academic journals edited by Michael Peters: Knowledge Cultures (Addleton), and The Video Journal of Education and Pedagogy (Springer). It explores epistemic consequences of peer-to-peer and wisdomof-the-group approaches, introduces the notions of collective intelligence and col(labor)ation, and outlines the main features of the new collective imagination. Finally, it shows that doing science is a privilege and a responsibility, and points towards transformation of academic labor from perpetuation of capitalism towards subversion.
\end{abstract}

Keywords: cybernetic capitalism; openness; col(labor)ation; knowledge cultures; collective intelligence; creative labor 


\section{Cybernetic Capitalism and the New Forms of Openness}

PJ: The age of information is dialectically intertwined with new social arrangements - slowly but surely, we have arrived into the age of cybernetic capitalism. Some authors, such as Manuel Castells (2001) and Jan van Dijk (1999), argue that we have entered a new knowledge-based society which has completely transformed our civilization. Others, such as Peter McLaren, claim that "we have not in any way left the smokestack era of factory production" (McLaren, 2006; McLaren \& Jandrić, 2014: 807), and that the notion of knowledge-based society is a mere smokescreen for traditional inequalities such as class and race. Are we really building a new, conceptually different type of society, or the oft-used "discourse of exceptionality" (Morozov, 2013) is exaggerated? Could you please position transformation from the mass society characterized by one-way analog technologies to the network society characterized by digital media in a wide(r) historical context?

MP: Without a doubt, we are entering the epoch of digital reason. The evidence is all around us and irrefutable. Of course, industrial capitalism is still dominant, but it is weakening hugely. One only has to look at the 500 largest companies in the world, and the move from oil and gas to business sectors we might call digital utilities. The question of the move from industrial to postindustrial is a discourse now over 40 years old. It is complex and not associated with any one kind of politics. There are conservation, neoliberal and Marxist views of this transition. While it is also a case of evolutionary transition, the emergence of global digital systems does not mean the end of factories - even though it may mean their automation and digitization. Above all, it is not a matter of either/or but rather and/both, in terms of an evolutionary approach towards a new political economy based on the development of digital logics and digital technologies.

I have written many books around this topic and its consequences: Building Knowledge Cultures (Peters and Besley, 2006), Imagination: Three Models of Imagination in the Age of the Knowledge Economy (Murphy, Peters \& Marginson, 2010), Education in the Creative Economy: Knowledge and Learning in the Age of Innovation (Araya and Peters, 2010), and Cognitive Capitalism, Education and Digital Labour (Peters and Bulut, 2011). Both Dan and Ergin were PhD students from Illinois and Rodrigo Britez with whom I wrote Open Education and Education for Openness (Peters and Britez, 2008) was also. I do believe in col(labor)ation - a theory that I propose as a basis of new forms of openness that is one of the characteristics of digital cultures.

PJ: One important phenomenon that characterizes our modernity is the transformation from disciplinary society to society of control. According to Deleuze, 
We're definitely moving toward 'control' societies that are no longer disciplinary. Foucault's often taken as the theorist of disciplinary societies and of their principal technology, confinement (not just in hospitals and schools but in schools, factories, and barracks). We're moving toward control societies that no longer operate by confining people but through continuous control and instant communication (Deleuze, 1995: 174).

Much has been written about markets as the main disciplinary technology of today (Peters, 2012a; Peters \& Olssen, 2011). This is especially the case in regards to public education, which has been increasingly commodified and subject to interest of the capital. Apart from money, however, there are other powerful social forces at play. Information technology has a conflicting role in the creation of the society of control. On the one hand, it brings frightful opportunities for technical control; at the other hand, it opens new spaces and opportunities against control. Could you please assess the role of digital technologies, and the Internet in particular, in the making of the society of control? How does it reflect to contemporary education?

MP: Let me refer to a recent paper for a Latin American collection focused on Foucault's Discipline and Punish after forty years: "Disciplinary Technologies and the School in the Epoch of Digital Reason." In this paper I wrote:

I will argue that within 'societies of control,' if we are to adopt Deleuze's term, or what I prefer to call 'the epoch of digital reason,' education rather than the prison becomes the primary model institution of social control that breaks the mold of spatial enclosure of the classroom or the lecture hall, to adopt different forms of digital logic that turn the classroom and the lecture hall inside out. The spatial enclosure becomes spatialized in a different manner as loose, scaleable and connected networks that take on global proportion that in every way exceeds the State and its territory. This process of digital logic opening up spaces of enclosure provides a very different institutional setting, much decentralized and autonomous within the network but linked in such a way that constitutes a system for data harvest of all behavioral characteristics. In these new network spaces disciplinary technologies are intensified and closely associated with the calculative rationality of algorithms that drive the information and search system.

In the epoch of digital reason, exemplified by the advent of the Internet and the adoption of open architectures, platforms and networks, all modern spaces of enclosure are opened up to external global forces that exhibit themselves through the combination of the market and new digital technologies. We can understand the operation of global market forces through an analysis of neoliberal globalization that at once promotes policies of deregulation, dezoning, decentralization on the one hand, and encourages both 
privatization and monopolization on the other. Digital logic permits a scalability of operations that is truly global as witnessed by the spectacular growth of the info-utility US-based transnational corporations such as Google, Facebook, and Amazon.com. These transnational corporations are the new configuration of global companies that are at the heart of 'knowledge capitalism' (Peters \& Besley, 2006). In the era of digital reason dominated by knowledge capital corporations, "education" (not just schools) considered in the widest sense and at all levels becomes the dominant means of providing digital labor for global knowledge capitalism (Peters \& Bulut, 2011).

This process of opening up modern spaces of enclosure spells the end of all modern institutions that once comprised disciplinary societies. Digital logics turn these institutions inside out and open them up through the process of promoting a greater interconnectivity and nested set of networks that hook them up in multiple configurations. This process is just beginning and represents an early stage of computerization and networking - from closed to open spaces. Yet disciplinary technologies still operate in schools and universities to provide forms of continuous control and surveillance within open platforms and architectures in ways that occlude the juridico-political theory of sovereignty by virtue of its extraterritoriality. Foucault's "panopticonism" based on Bentham's design to make possible surveillance within the prison, now becomes the principle and metaphor for surveillance in 'open structures' of the digital age. The generalizable mechanism of 'panopticonism' becomes even more possible and prevalent in the digital age by developing the surveillance gaze of the State and the corporation of global populations that use new technologies to observe, surveil, track, monitor, and tag subjects while at work, at home, and at play. The Panopticon digitally enhanced creates a consciousness of permanent visibility and data capture as forms of power, where spatial enclosure and lock ups are no longer necessary for control any more. The new visibility is supplemented through all forms of metrics including bio-metrics and bibliometrics that can continuously track, 'listen,' monitor and tag our movements, our conversations, and our purchases. Education in the epoch of digital reason exemplifies the disciplinary power of surveillance and mechanisms of control in terms of increasingly global systems of 'big data' and leaning analytics that delivers public education into the hands of the info-utility transnational corporations. (Peters, forthcoming)

PJ: Capitalism, traditional and new, has always been linked to openness Karl Popper and The Open Society and Its Enemies (1974) is a typical case in the point. However, in the opposite ideological camp - from counterculture of the 1960s, through early makers of digital technologies, to recent hackers and Internet activists (Turner, 2006 \& 2013; Assange, Appelbaum, Müller- 
Maguhn \& Zimmermann, 2012) - openness is also understood as a subversion of capitalism. Could you please analyze the dynamics between openness, capitalism, and anti-capitalism?

MP: The dynamics of which you speak refers centrally to the forms of openness and closure around the propertarian paradigm of intellectual property and ownership of ideas. There are of course many different kinds of openness as geopolitics, as political economy, as ethical economy. Globalization as political openness takes different political forms (with no guarantees). For example:

(i) гла́сность - Glasnost (literally openness), 1980s - Glasnost was a policy that called for increased openness and transparency in government institutions and activities in the Soviet Union introduced by Mikhail Gorbachev that signified less censorship and more freedom of information. The term was used also as a means to combat political corruption. It came to represent a set of reforms that led to less censorship, greater transparency and freedom of information especially during the 1980s. These reforms are forms of the introduction of "open government." A movement that began in the 1960s to promote freedom of information and picked up greater gravitas in the western world with the passage of legislation designed to make the state more transparent to its citizens.

(ii) 邓小平理论 - Deng Xiaoping “Opening Up," 1978-1989. In the postCultural revolution the theory of "opening up" was initially based on the customized thought of Mao Zedong. It included four modernizations after 1978 (economy, agriculture, scientific and technological development and national defense) that were designed to open up the economy and normalize business with U.S. under the banner "Socialism with Chinese characteristics" - meaning socialism and market economy are not incompatible. In 1984, UK agreed to return Hong Kong in 1997, and in 2001, China joined the WTO, thus completing the first phase of opening up China to the rest of the world. In 1981, in line with his famous statement of Chinese pragmatism - "it doesn't matter whether a cat is black or white, if it catches mice it is a good cat" - Deng Xiaoping began to open up and liberalize the Chinese economy. This was primarily a form of economic openness with some political concessions but the real question is whether the economic reforms will necessitate greater political openness.

(iii) The Arab Spring, 2010 - Openness and democracy. In Tahrir Square, Cairo, there were calls for "freedom" - freedom from "sultanistic" tyranny. The freedom movement drew on the history of non-violent movements: Rosa Parks, Martin Luther King, and Malcolm X. It did not use the language of global capital but was based around indigenous understandings of citizenship, rights and social justice. The protests began in 2010. By 2015, rulers in power in Tunisia, Egypt, Libya and Yemen had been forced out and protests had begun in Bahrain, Syria, Algeria, Iraq, Jordan, Kuwait, 
Morocco and Sudan. In most cases, youth demonstrated en masse against unsatisfactory rule of dictators who had routinely violated human rights and engaged in political corruption. The aftermath has been characterized by widespread violence and regional instability, resulting in huge number of deaths and refugees. Clearly, social media and new digital technologies played a decisive role in undermining state media, coordinating protests and fomenting political change. It is too soon to say what the long term impacts of these populist uprisings will be, and whether the democratic promise will be redeemed.

(iv) The Occupy Movement, 2011 - With roots in the Arab Spring and protest against anti-austerity measures, the Occupy Movement began as a protest against Wall Street and finance capitalism. Adbusters co-founder Kalle Lasn has compared the protests to the Situationists and 1968 (Lasn and Elliott, 2011). Douglas Rushkoff called it “America's first true Internet-era movement" (2011). Here is a form of protest based on social media networking where social media are used as tools for political coordination.

Of course, there are historical reversals too: Where did the Arab Spring go? What happened to these experiments in democracy? What has happened to Russia under Putin? In the latter case, we are definitely witnessing a systematic movement away from the democratic reforms of the early 1990s toward a closed secret society based on the cult of Putin and strongman dictatorship.

\section{Col(labor)ation and Knowledge Cultures}

PJ: Can you relate openness and cybernetic capitalism to learning and knowledge production?

MP: With the advent of the Internet, principles of openness have become the basis of innovative institutional forms that decentralize and democratize power relationships, promote access to knowledge, and encourage symmetrical, horizontal peer learning relationships. New "peer philosophies" are at the heart of a notion of "openness" that would advocate the significance of peer governance, peer review, peer learning, and peer collaboration as a collection of values that form the basis for open institutions and open management philosophies. These in turn offer significant implications for localized and individual empowerment, where learners can work together using effective pedagogies to meet the needs of their communities.

We can consider open publishing, open access and archiving as parts of the wider movement called Open Education that builds on the nested and evolving convergences of open source, open access and open science, and also emblematic of a set of still wider political and economic changes. Open education ushers in "social production" as an aspect of the global digital 
economy, an economy that is both fragile and volatile as the current world credit and banking crisis demonstrates so well. The present decade can be called the "open" decade (open source, open systems, open standards, open archives, open everything), just as the 1990s were called the "electronic" decade (e-text, e-learning, e-commerce, e-governance). And yet, it is more than just a "decade" that follows the electronic innovations of the 1990s. It is a change of philosophy and ethos, a set of interrelated and complex changes, that transforms markets and the mode of production, ushering in a new collection of values based on openness, the ethic of participation and peerto-peer collaboration.

Intellectual property is the major mechanism for securing forms of human capital in the knowledge economy. Of course, the intellectual commons is the exact opposite of this enclosure trying to make ideas free. Popper is more of a democrat than Hayek whose early work was based on a theory of information as a basis for open markets. On the other side, there are those like Yochai Benkler, Steven Johnson and Michel Bauwens, who have made the case in different ways for open commons and for open knowledge production (one of my interests). Their arguments to my mind proceed from the social character of knowledge (Marx, Wittgenstein, Heidegger, Dewey), that provides the basis for various critiques of the notion intellectual property including: information is not property, is not non-rivalrous, wants to be free, free speech arguments, the social nature of information, cost of digital publishing (see Moore and Himma, 2014).

PJ: In Virtues of Openness, you develop a fascinating Freirean perspective to openness as an (educational) virtue (Peters \& Roberts, 2012: 47). Could you please explain the roots of this perspective? What are its main advantages and limits?

MP: It is again another form of openness that figures differently in the writings of the defenders of liberal modernity from Dewey, to Popper to Habermas - and now also Pierce as an advocate of the "community of inquiry" that requires openness in various forms to promote the value of freedom of speech or self-expression as a virtue of cultural action and liberation. There are many ways to understand the link between openness and freedom:

- Free speech (as a primary right) promotes the free exchange of ideas essential to political democracy and its institutions, especially as embodied in the institution of a "free press" with its new open formats.

- Free speech promotes the flow of ideas and diversity necessary for innovation and the marketplace, especially in the new mix between public architectures and infrastructures on the one hand and the large scale of the info-utilities on the other. 
- Free speech promotes depends upon, but is not limited to, the search for truth and truth as a basis for a community of inquiry.

- Free speech is also a significant personal, psychological and educational good that promotes the quality of self-expression and thereby the autonomy and development of self, impinging on questions of self-representation and identity.

- Free speech is a fundamental right that is the hub for a range of academic rights including the right to learn, the right to access to knowledge and information, the right to basic education, and the right to publish.

- Free speech provides a limit to the ability of the State to subvert other rights and freedoms.

- Free speech in the ancient Greek - parrhesia $(\pi \alpha \rho \rho \eta \sigma i ́ \alpha)$ - is regarded as a fundamental element of democracy in classical Athens based on the freedom to say (almost) anything, and also appears in the Midrashic literature connoting open and public communication analogous to the Commons or the Public Domain (see Foucault, 1983).

- Free speech associated with digital rights have been theorized and legislated for in terms of Internet Rights and principles (Peters, 2014).

- Free speech is a necessary condition for an open community of inquiry (Dewey, Popper, Pierce) - Western education and science embrace this model.

- Free speech as a condition for freedom is a form of cultural action (Freire).

PJ: Your recent book, The Creative University, shows the advent of knowledge society has brought along "creativity as the new development paradigm" (Peters and Besley, 2013: 3). Could you please link openness and creativity? MP: This is one of the key arguments I have been trying to make in a variety of ways. By emphasizing the link between openness as freedom (especially freedom of speech and of expression) as a political condition for creativity. By trying to demonstrate that, psychologically speaking, openness to experience (and the ability to change one's mind on the basis of evidence) is a precondition to creativity. By arguing that freedom of communication - of being able to communicate with anyone at all at any time (a form of open communication promoted by new communication technologies) - encourages an ethic of sharing and collaboration as the basis for forms of collective intelligence. By stressing that the "open mind" psychologically correlates well with personality traits that indicate tolerance, sensitivity and acceptance of the other. In particular, I make the link between openness and creativity through user-generated cultures - see Chapter 2 of The Pedagogy of the Open Society (Peters, Liu and Ondercin, 2012) and also Virtues of Openness (Peters and Roberts, 2012).

PJ: An important part of your work is related to academic publishing. You edit numerous journals and books, and also research the changing nature of contemporary knowledge - in short, your rich publishing engagement is a true 
act of critical praxis. Along these lines, you recently wrote that your "work as an editor demands that I have a working political economy of academic publishing and also a philosophy of technology" (in Stickney, 2014: 261-266). Could you please describe your political economy of academic publishing?

MP: My political economy starts with the idea that intellectuals and academics need to understand something about the material and historical forms their ideas take in journal systems, in books, and now in digital forms. In this way, we can take control of our own labor processes and understand the potential to take control and re-establish new forms of global civil society and new public spaces. So this means actually doing things, i.e. working in the world of academic publishing and experimenting with its forms. It means understanding the significance of editing and of new digital forms of publishing. It means trying to understand the material and historical contexts of the creation of ideas.

PJ: In the first part of this conversation (Peters \& Jandrić, 2015), you said that the current state of the art of educational philosophy "is such an important question I would like to make it the centre of a conference or journal issue". In your Liber amicorum, Tina Engels-Schwarzpaul writes: "Michael told me once that, if he wants to learn something about a particular topic, he will edit a book - a process he also used with his students for doctoral seminars or individual theses" (2014: 3015). Few weeks ago, without knowing all that, I supported my editorial engagement in Knowledge Cultures to my supervisor using a very similar argument - I just want to learn about the topic of the Special Issue!

In my humble experience, (academic) editing is so many things at once. Editing is service, because it filters and systematizes other people's research; editing is a research approach, because such filtering and systematization may produce new knowledge; editing is also a route to personal development, because it (ideally) widens horizons of everyone involved in the process. For Nicholas Burbules, editing implies "an active, dialogical role - sometimes as much like a collaborator or co-author as an editor" (in Stickney, 2014: 234). Based on your impressive engagement spanning through several decades, Michael, how do you conceive (academic) editing? What is its significance in contemporary science? How did it arrive to such a special place in your opus?

MP: Academic editing is a set of skills that is essential to academic writing and publishing and also deeply involved with process of peer review. That is the cornerstone of scholarship and the enterprise of science itself. The skills of editorship, not just the act of editing, of course entail making judgments about academic work, whether a piece of research passes muster, whether it has met criteria for acceptability, whether it can be read and understood by a larger audience. I want to give it a very large role in the larger movement of scholarship, because for me it carries certain responsibilities of mentoring the 
younger scholars, of resolving different assessments of the same research, of encouraging constructive criticism. Editorship and editing stand at the very centre of knowledge production.

Remember it was Henry Oldenburg, as the first editor of the Philosophical Transactions of the Royal Society, who wrote the first reports that comprised the journal. Peer review did not kick in for another hundred years (1731 from memory, introduced by the Royal Society in Edinburgh for reason of indemnifying the institution). It seems curious to me that institutionalized science was developed about 300 years ago, and now drives a global knowledge system based on journal systems - some 18,000 academic journals that carry some 3 million articles per year. I place a great deal of faith in science and in the way that open scientific inquiry can eventually sort out the issues and arrive at truthful conclusions. So editing and editorship, especially in relation to journals, is an important part of this modern experiment.

PJ: Such approach to editing is closely related to the concept of knowledge cultures invented by you and Tina Besley (Peters and Besley, 2006)...

MP: I have begun to give some of the essentials of an account of "knowledge cultures" around questions of co(labor)ation - as opposed to human capital what I regard as a form of "creative labor." I have written about this elsewhere under the term "radical openness." The outlines of knowledge cultures can also be seen in my remarks about co-creation and co-production. The guiding argument concerns the social character of knowledge. Knowledge and the value of knowledge are rooted in social relations - the argument I derive from Marx and Wittgenstein. Knowledge cultures are epistemic communities of inquiry, both in a Kuhnian and Peircean sense. We used the term also deliberately to drive a wedge between "economy" and "society."

\section{From Human Capital to Creative Labor}

PJ: With Addleton publishers, you started an academic journal entitled Knowledge Cultures. How does it embody your theoretical insights in practice?

MP: Actually, if I might broaden the question a little, I would like to try and capture an insight about ideas. After the ideation phase, ideas have a material embodiment - normally in terms of a codification in symbols, in language, and often in oral or written forms - when they become embodied in texts. I embrace a materialist view of ideas and a historical one: the forms of thought embodied in language are expressed in different genres. So in philosophy we have many different genres from the dialogue through the treatise to the thesis. Academic writing also takes various forms: the pervasiveness of the monograph and the scientific article is a product of an industrial age. I say to my students "the article is a dirty little industrial machine," trying to make the point about homogenization and standardization of scientific thought. In 
part, I wrote about this in Academic Writing, Philosophy and Genre (Peters, 2009) and also in Philosophy's Pedagogy (Peters and Patel, 2010).

My point here is that I try to link the intellectual (academic) process with the publishing process. As academics we must take more responsibility for the form our thinking takes. I established Knowledge Cultures when my good friend George Lăzăroiu, a Romanian philosopher living in New York and one of the inspirations for Addleton Academic Publishers, asked me if I was interested in establishing a new journal. As it was, I had been thinking about a new journal for a while, and floated the idea with a couple of publishers who did not grasp the idea, or if they did, they did not like it. Here is the description I drafted back in 2012 for the journal website:

Knowledge Cultures is a multidisciplinary journal that draws on the humanities and social sciences at the intersections of economics, philosophy, library science, international law, politics, cultural studies, literary studies, new technology studies, history, and education. The journal serves as a hothouse for research with a specific focus on how knowledge futures will help to define the shape of higher education in the twenty-first century. In particular, the journal is interested in general theoretical problems concerning information and knowledge production and exchange, including the globalization of higher education, the knowledge economy, the interface between publishing and academia, and the development of the intellectual commons with an accent on digital sustainability, commons-based production and exchange of information and culture, the development of learning and knowledge networks and emerging concepts of freedom, access and justice in the organization of knowledge production. (Peters, 2012b)

As you can see, I was searching for a new ecology of disciplines to address a new set of issues for the university. I have been editing journals for a long time. I have been editor of Educational Philosophy and Theory (Routledge) since 1999 and I established two journals when I was in Scotland - Policy Futures in Education and E-Learning and Digital Media (both SAGE journals now). Next year, I am to establish The Video Journal of Education and Pedagogy as a Springer journal.

PJ: Different ways of producing knowledge produce different kinds of knowledge. Therefore, the upcoming The Video Journal of Education and Pedagogy challenges the very basis of knowledge production by transferring it into another medium. At a more generic level, video journals and other new forms of scholarship are mere symptoms of social transformation from "textual cultures" to "visual cultures." Walter Benjamin, Guy Debord, Jean Baudrillard, Gilles Deleuze, and many others, have explored various aspects of this transformation in regards to knowledge. In Imagination: Three Models 
of Imagination in the Age of the Knowledge Economy, you outline "pedagogies as ways of seeing" by saying:

Pedagogies of visual culture would seek to understand both the meaning of images, the way in which they comprise a language and help us to analyse vision as a social, cultural and historical process. It would examine the history of changing technologies that are involved in the production, circulation, and reception of images as well the exploration of theories of seeing and looking as social and cultural practices. (Peters, 2010: 352).

Could you analyze the role of images (and, in relation to your new journal, the role of video), at the intersections of knowledge creation and learning? At the level of practice, what is it exactly that you expect from your new journal? MP: It is probably a little early to answer this question, because the journal which I have been thinking about for a couple of years isn't to be launched until early 2016. I am also constrained in terms of innovation, because - as much as I would like for it to be free - I have chosen to go with a big publisher (Springer) who has the resources to sustain this venture. The Video Journal of Education and Pedagogy is the first in education, maybe in the humanities and social sciences, to base itself on moving images. What I call the "video article" will take a precise form: introduction, research question, literature discussion, video (15 minute clip), discussion and bibliography. Small steps to start with, as we have to get academics used to this idea and also publishers.

My idea was rejected several times by other publishers until I hit upon a sustainable business model. The role of images will take different forms: interviews (ahem!), clearing house for extant address and keynotes, videos in various classes (demonstrations of teaching, classroom observation), performance (music, dance etc), indigenous studies, and so on. We will also build in a component which will be dedicated to visualization methodologies. (Here I can smuggle in questions concerning philosophy of visual cultures.) One issue that looms large is of course the ethics of video and its representation. But ask me again after the journal has been running for a year! All my optimism might have drained away; but I think it is worth an experiment. Philosophy and pedagogy have been wedded both to the oral and written forms - now they require new media including video. What this means for academic work will be an interesting question.

PJ: Lot of your work is based on peer-to-peer dialogue and the wisdom of the group. Could you please explore epistemic consequences of such approach? MP: I would classify peer-to-peer as a form of collective intelligence and I think that potentially we can identify various literatures on or related to the questions of collective intelligence: 
- Political - epistemic democracy.

- Biological - "swarm intelligence," social insects.

- Administrative, public policy - co-creation and co-production of public services, peer production.

- Cognitive - the embodied mind (extended, embedded, enacted), social cognition.

- Technological - artificial intelligence, social media, machine learning.

- Evolutionary - the cumulative effects and evolutionary development of cultural inventions (like writing) that encourage media that promote social or collective intelligence and collective action.

The concept of collective intelligence is prefigured in political philosophy and in related notions like "collective consciousness" (Carl Jung). It emerged later in the study of social insects, and then in the synergies of open source, networked and social media technologies based on the Internet.

In an early application in 1785, the Marquis de Condorcet wrote Essai sur l'application de l'analyse à la probabilité des décisions rendues à la pluralité des voix (Essay on the Application of Analysis to the Probability of Majority Decisions). The essay includes what is known as Condorcet's jury theorem that gives the relative probability of a given group of individuals arriving at a correct decision. His theorem has led to studies of the logic of majority judgments (Hawthone, 2009) and to notions of epistemic democracy (List \& Goodin 2001), where the concern is more for the social-decision tracking of truth than fairness, though democracy can be justified either way. This approach seeks to generalize Condorcet's jury theorem. Elizabeth Anderson investigates the epistemic powers of democratic institutions through an assessment of three epistemic models of democracy, including the Condorcet Jury Theorem, to argue for Dewey's experimentalist model that defined "democracy as the use of social intelligence to solve problems of practical interest (Dewey 1981; Putnam 1990)" (Anderson, 2006: 13). David Estlund (2007) explains that there is a great deal of variety in epistemic approaches to democracy based on the value of free public discourse that epistemologically guides political practice.

Others philosophers have assumed that there is an intimate connection between epistemology and democracy - Rousseau, Mill, Peirce, Dewey, Habermas, Rawls, and Rorty. In particular, for me it is useful to focus on Peirce's accounts of the logic of the "community of inquiry."

PJ: Throughout this conversation, you mentioned collective intelligence and col(labor)ation in several different contexts - however, I find it a bit hard to connect bits and pieces into a full image. Could you please outline these concepts?

MP: OK, I am no expert in any of these matters, but let me try my hand at this. I am interested in understanding models of the "new social" in terms of 
collective intelligence: social media, social innovation, social production, social democracy. All have come of age in the new digital environment. Here, there are also various forms of collectivity: from collective awareness, collective intelligence and collective wisdom, to collective action. These are only rough and ready typologies that I have invented to make sense of a varied field.

Now "creative labor" is a term I used in contradistinction to "human capital." I wanted explicitly to take issue with human capital that theorizes labor from the viewpoint of capital - and collective behavior as "social capital" from the viewpoint of labor. If we are talking about the new social, and about forms of collective intelligence that become vitally important in the digital age, then I want to spawn a concept that might capture the elemental creative processes that exist in human systems. These processes have no central control. Therefore, they are autonomous of governments, states or authorities. The Internet as platform seems well suited to harnessing these collective forms based on creative labor, that are involved in co-production often when the profit motive is entirely absent.

PJ: Your contribution to Imagination: Three Models of Imagination in the Age of the Knowledge Economy starts with a powerful sentence: "There is no more central issue to education than thinking" (Peters, 2010: 329). You move on to analyze kinds of thinking and styles of reasoning, and conclude that the Web contributes to "a new age of collective imagination." Arguably, however, people have always imagined collectively - typical case in the point is "the American Dream." What are the main features of the new collective imagination? How does it differ from its historical counterparts?

MP: The American dream is an individual historical construction that was invented by James Truslow Adams in 1931 that was then read backwards and forwards against various events in American history. I provided an extended discussion of this in my book Obama and the End of the American Dream: Essays in Political and Economic Philosophy. If I can quote from the synopsis, for the sake of space:

The American Dream that crystallized around James Truslow Adams' The Epic of America originally formulated in the early 1930s and was conditioned by a decade of complexity and contradiction, of big government projects, intensely fierce nationalism, the definition of the American way, and a distinctive collection of American iconic narratives has had the power and force to successively reshape America for every new generation. Indeed, Adams' dream of opportunity for each according to ability or achievement shaped against the old class culture of Europe emphasizes a vision of social order in which each person can succeed despite their social origins. Barack Obama, a skillful rhetorician and intelligent politician, talks of restoring the American and has used its narrative 
resources to define his campaign and his policies. (Peters, 2012a:

vii)

In my piece on thinking, I embrace a material view in terms of "kinds of thinking" and "styles of reasoning." "Collective imagination" is another process I should have alluded to above, but it is not perpetrated, controlled or ideologized by an individual or small group for reasons of selling a policy or an idea. Rather, it is a genuine participation in crafting and living the narrative which is a kind of collective action designed to enhance the well-being of humanity.

PJ: Please allow me to bring this conversation to an end with a brief introspective look. You, I, and many other academics throughout the world, spend our days reading, writing and talking. Doing science has always been a privilege - and the one that should be enjoyed with responsibility and care. What happens to this privilege in the age of cognitive capitalism? How can we transform our (digital) labor from perpetuation of capitalism towards subversion?

MP: A great question - all your questions have been insightful and I have enjoyed collecting my thought to answer them. Doing science is a privilege and a responsibility, I agree entirely. And we should never forget to theorize our own privilege nor take for granted our position as scholars and researchers - especially, but not only, when our work involves human subjects - children or members of a disadvantaged group. These are ethical questions and there have been on-going debates about research ethics and "western science" now for some years. In psychology, especially the question of informed consent has often gone unnoticed. In the era of cognitive capitalism, digital labor becomes the commodity. Then, education at all levels is co-opted into providing "digital labor" in the same way that factory owner of the industrial age demanded "skilled labor." In the first instance, we have to understand the position of the school and the university under cognitive capitalism. We need to understand and deconstruct "the epoch of digital reason" and all of its manifestations as they unfold historically. As we do this, we can see asymmetries of power that can be exploited, and new assemblages and opportunities to develop new forms of openness. These forms may be represented as a set of overlapping shared spaces that might reconstitute "the social" at the global level: social media, social production, social innovation, social democracy. All thrive on collective intelligence and what I call "creative labor." Creative labor that theorizes creativity from the point of labor rather than capital is the antithesis of human capital and points towards a cultural evolution that some have referred to as "cognitive economy" or "cognitive capitalism." I am not as optimistic as Hardt and Negri, but I do see new social potential in this emerging paradigm. 


\section{REFERENCES}

Anderson, E. (2006), “The Epistemology of Democracy," Episteme: A Journal of Social Epistemology 3(1): 8-22.

Araya, D., and Peters, M. A. (eds.) (2010), Education in the Creative Economy: Knowledge and Learning in the Age of Innovation. New York: Peter Lang.

Assange, J., Appelbaum, J., Müller-Maguhn, A., and Zimmermann, J. (2012), Cypherpunks: Freedom and the Future of the Internet. New York: OR Books.

Castells, M. (2001), The Internet Galaxy: Reflections on the Internet, Business, and Society. Oxford: Oxford University Press.

Deleuze, G. (1995), Negotiations 1972-1990. New York: Columbia University Press.

Dewey, John (1981), "Creative Democracy: The Task before Us," in J. A. Boydston (ed.) The Later Works of John Dewey, 1925-1953, vol. 14. Carbondale, IL: Southern Illinois University Press, 224-230.

Engels-Schwarzpaul, A. C. (2014), "Not a Docile Body - A View from the Inside: Michael A. Peters on Foucault," in G. Lăzăroiu (ed.), Liber amicorum: A Philosophical Conversation among Friends. New York: Addleton Academic Publishers, 49-64.

Estlund, D. M. (2007), Democratic Authority: A Philosophical Framework. Princeton, NJ: Princeton University Press.

Hawthorne, J. (2009), "Voting in Search of the Public Good: The Probabilistic Logic of Majority Judgments." Retrieved 22 March 2015 from http://faculty-staff.ou .edu/H/James.A.Hawthorne-1/Hawthorne--Jury-Theorems.pdf.

Lasn, K., and Elliott, J. (2011), "The Origins of Occupy Wall Street Explained: An Interview," Salon, 4 October. Retrieved 22 March 2015 from http://www.salon. com/2011/10/04/adbusters_occupy_wall_st/.

Marquis de Condorcet (1785), Essai sur l'application de l'analyse á la probabilité des décisions rendues á la pluralité des voix. Retrieved 22 March 2015 from http://gallica.bnf.fr/ark:/12148/bpt6k417181.

McLaren, P., and Jandrić, P. (2014), "Critical Revolutionary Pedagogy Is Made by Walking - in a World Where Many Worlds Coexist," Policy Futures in Education 12(6): 805-831.

McLaren, P. (ed.) (2006), Rage and Hope: Interviews with Peter McLaren on War, Imperialism, and Critical Pedagogy. New York: Peter Lang.

Moore, A., and Himma, K. (2014), "Intellectual Property," in E. N. Zalta (ed.), The Stanford Encyclopedia of Philosophy (Winter 2014 Edition). Retrieved 7 March 2015 from http://plato.stanford.edu/archives/win2014/entries/intellectual-property/.

Morozov, E. (2013), To Save Everything, Click Here: The Folly of Technological Solutionism. New York: Public Affairs.

Murphy, P., Peters, M., and Marginson, S. (2010), Imagination: Three Models of Imagination in the Age of the Knowledge Economy. New York: Peter Lang.

Peters, M. (2012b), “Knowledge Cultures.” Retrieved 22 March 2015 from http:// www.addletonacademicpublishers.com/knowledge-cultures.

Peters, M., and Olssen, M. (2011), "Neoliberalism, Higher Education and Knowledge Capitalism," in M. A. Peters (ed.), Neoliberalism and After?: Education, Social Policy, and the Crisis of Western Capitalism. New York: Peter Lang, 42-74. 
Peters, M. A. (2010), "Model Three: Re-Imagining Education," in P. Murphy, M. Peters, and S. Marginson (eds.), Imagination: Three Models of Imagination in the Age of the Knowledge Economy. New York: Peter Lang, 329-382.

Peters, M. A., and Besley, T. (2006), Building Knowledge Cultures. Lanham, MA: Rowman \& Littlefield.

Peters, M. A., and Besley, T. (2013), The Creative University. Rotterdam: Sense.

Peters, M. A., and Bulut, E. (eds.) (2011), Cognitive Capitalism, Education and Digital Labor. New York: Peter Lang.

Peters, M. A., and Jandrić, P. (2015), "Philosophy of Education in the Age of Digital Reason," Review of Contemporary Philosophy 14: 162-181.

Peters, M. A., and Patel, R. (2010), "Philosophy's Pedagogies - Dialogue or Street Talk?," Nordic Studies in Education 4: 201-213.

Peters, M. A., and Roberts, P. (2012), The Virtues of Openness: Education, Science and Scholarship in the Digital Age. Boulder, CO: Paradigm.

Peters, M. A. (1999), After the Disciplines: The Emergence of Cultural Studies. Westport, CT: Bergin \& Garvey.

Peters, M. A. (2009), Academic Writing, Philosophy and Genre. London: WileyBlackwell.

Peters, M. A. (2015), "Disciplinary Technologies and the School in the Epoch of Digital Reason," in S. Gallo and A. Filordi (eds.), Foucault's Discipline and Punish after Forty Years. Forthcoming

Peters, M. A., Liu, T. C., and Ondercin, D. J. (2012), The Pedagogy of the Open Society: Knowledge and the Governance of Higher Education. Rotterdam: Sense.

Peters, M. A., and Britez, R. G. (2008), Open Education and Education for Openness. Rotterdam: Sense.

Peters, M. A. (2012a), Obama and the End of the American Dream: Essays in Political and Economic Philosophy. Rotterdam: Sense.

Popper, K. (1974), The Open Society and Its Enemies. London: Routledge.

Putnam, H. (1990), “A Reconsideration of Deweyan Democracy," Southern California Law Review 63: 1671-1697.

Roberts, P. (2014), "Endless Energy: Portrait of an Intellectual,” in G. Lăzăroiu (ed.), Liber amicorum: A Philosophical Conversation among Friends. New York: Addleton Academic Publishers, 24-31.

Rushkoff, D. (2011), “Think Occupy Wall St. Is a Phase? You Don’t Get It,” CNN, 5 October. Retrieved 22 March 2015 from http://edition.cnn.com/2011/10/05/ opinion/rushkoff-occupy-wall-street/index.html.

Stickney, J. (2014), "Philosophical Fellowship: An Interview with Michael Peters and Nicholas Burbules," in G. Lăzăroiu (ed.), Liber amicorum: A Philosophical Conversation among Friends. New York: Addleton Academic Publishers, 1-24.

Turner, F. (2006), From Counterculture to Cyberculture: Stewart Brand, the Whole Earth Network, and the Rise of Digital Utopianism. Chicago, IL: University of Chicago Press.

Turner, F. (2013), The Democratic Surround: Multimedia and American Liberalism from World War II to The Psychedelic Sixties. Chicago, IL: University of Chicago Press.

van Dijk, J. (1999), The Network Society. London: Sage. 